\title{
Cryptic diversity and population structure at small scales: the freshwater snail Ancylus (Planorbidae, Pulmonata) in the Montseny mountain range
}

\author{
Jan N. Macher*, Martina Weiss, Arne J. Beermann and Florian Leese \\ Aquatic Ecosystem Research, University of Duisburg-Essen, Universitätsstraße 5, 45141 Essen, Germany
}

Received 11 May 2015; Accepted 12 September 2016

\begin{abstract}
Anthropogenic impacts like intensified land use and climate change are severe threats to freshwater biodiversity and effective biodiversity monitoring is therefore one of the most urgent tasks. This is, however, often hampered by the lack of knowledge regarding the number and ecology of species. Molecular tools have shown many freshwater taxa to comprise morphologically cryptic species, which often occur in sympatry on a small geographic scale. Here, we studied the freshwater snail Ancylus fluviatilis (Müller, 1774) species complex in the Iberian Montseny Mountains. We hypothesized that (1) several species of A. fluviatilis sensu lato occur in the Montseny and (2) the different species seldom co-occur in syntopy due to different ecological demands or interspecific competition. We barcoded 180 specimens from 36 sites in the Montseny for the cytochrome c oxidase subunit I (COI) barcoding gene and molecularly identified two Ancylus species. These species seldom occurred in syntopy and a species distribution modelling approach showed differing bioclimatic preferences of the species. One species occurs mainly in cooler, higher altitude streams while the second species occurs in lower-altitude areas with higher temperatures. Tests of population structure showed that both species possibly do not disperse well in the study area and that populations within species might be adapted to certain bioclimatic conditions in different regions of the Montseny. Our results highlight the need to incorporate molecular techniques into routine monitoring programmes.
\end{abstract}

Key words: Cryptic species complex / barcoding / species distribution modelling / freshwater invertebrates

\section{Introduction}

Anthropogenic impacts like intensified land use and climate change are severe threats to biodiversity (Vörösmarty et al., 2010; Steffen et al., 2015). Therefore, monitoring the ongoing loss of biodiversity is highly important and many countries worldwide have established programmes to do so. However, the overall loss of biodiversity can only be monitored when accurate knowledge on the number, ecology, distribution and genetic diversity of species is available. For many areas and ecosystems, such information often either does not exist or is inaccurate: in recent years, the use of molecular methods has shown that the number of species is underestimated in many taxa (e.g. Amato et al., 2007; Pfenninger and Schwenk, 2007; Adams et al., 2014). This is especially true for freshwater ecosystems, which harbour a large number of morphologically indistinguishable or cryptic animal species (e.g. Pauls et al., 2010; Weigand et al., 2011;

\footnotetext{
*Corresponding author: jan.macher@uni-due.de
}

Weiss et al., 2014). The ecology of most cryptic species is, however, rarely known since it has been studied only for relatively few taxa (e.g. Ortells et al., 2003; Rissler and Apodaca, 2007; Lagrue et al., 2014; Fišer et al., 2015). This lack of knowledge poses a risk, since monitoring programmes and biodiversity assessments can come to inaccurate conclusions if species with different ecologies are treated as being identical regarding their ecological demands and thus, their suitability to indicate ecosystem health (e.g. Macher et al., 2016). Also, extinction events and loss of biodiversity can go unnoticed. In this regard, using molecular methods to study freshwater species in mountain ranges is especially promising since many mountain ranges have been shown to harbour a large number of cryptic freshwater species (e.g. Pauls et al., 2009; Katouzian et al., 2016; Mamos et al., 2016). Further, mountain ranges comprise many different habitats due to their topographic and climatic complexity, often leading to different species communities occurring within a small geographic area (Finn and Poff, 2005; Múrria et al., 2014; Cauvy-Fraunié et al., 2015). Topography and climate 
form natural barriers to dispersal and many taxa occurring in mountain ranges show phenotypic and genetic adaptation to the highly differing conditions along the altitudinal gradient (Liebherr, 1986; Bonin et al., 2006; Keller et al., 2013; Watanabe et al., 2014), ultimately leading to mountain ranges being centres of high biodiversity. Using molecular methods to study species in such environments can help understand species diversity, ecology and their possible genetic adaptation to different habitats. Furthermore, it can make it possible to infer the potential loss of species and genetic diversity when the environment changes.

Here, we analyzed diversity and spatial distribution patterns in a common European stream invertebrate taxon, the freshwater limpet Ancylus fluviatilis (Müller, 1774) sensu lato, in the Montseny mountain range on the Iberian Peninsula. The Montseny is part of the Catalan pre-coastal range (North East Iberian Peninsula). It is located at the intersection of the warm and arid climate of the Mediterranean lowlands and the cooler and more precipitation-rich climate of the mountainous region reaching to the Pyrenees (Thuiller et al., 2003). There are three main catchments within this area, all of which are characterized by steep altitudinal gradients ranging from less than 500 to $1706 \mathrm{~m}$ above sea level (masl) within approximately $10 \mathrm{kms}$ and thus, comprising highly variable climatic conditions (Peñuelas and Boada, 2003; Jump et al., 2007). We chose to study the widespread hololimnic freshwater limpet A. fluviatilis sensu lato, because it is known to comprise several cryptic species (Hubendick, 1970; Pfenninger et al., 2003; Albrecht et al., 2006). Of those species, Clade 1 and Clade 4 (Pfenninger et al., 2003) potentially co-occur in the North East Iberian Peninsula, but have never been found in the area studied here. On a European scale, Pfenninger et al. (2003) found that the different A. fluviatilis clades differ significantly in their ecological demands: while Clade 1 prefers cooler areas with precipitation-rich summers, Clade 4 occurs mainly in arid, generally hotter areas. Both climatic conditions can be found in the Montseny, making it an ideal area for studying the number and distribution of species within the A. fluviatilis species complex. A. fluviatilis sensu stricto is able to disperse over longer distances (Cordellier and Pfenninger, 2008), e.g. by passive transport via waterbirds and other organisms (Rees, 1965), a phenomenon commonly found in other snails and freshwater molluses (Rees, 1965; Boag, 1986; Van Leeuwen et al., 2012). The current distribution of species in the A. fluviatilis species complex is thus expected to be limited by ecological demands (Cordellier and Pfenninger, 2008).

In this study, we expected (1) to find morphologically cryptic species of the A. fluviatilis species complex in the Montseny mountain range, and (2) that different A. fluviatilis species seldom co-occur in syntopy due to different ecological demands or interspecific competition.

To test these hypotheses, we firstly analyzed the partial mitochondrial cytochrome $\mathrm{c}$ oxidase subunit 1 gene (COI) to determine the number and distribution of A. fluviatilis species found in the Montseny. Secondly, we used a modelling approach based on bioclimatic variables to identify variables that might help to explain the occurrence of species. In addition, we performed population genetic analyses to find possible intraspecific partitioning of genetic variation.

\section{Materials and methods}

\section{Sampling}

Sampling was performed in the Montseny mountain range (located on the North East Iberian Peninsula, Fig. 1a) and the direct surrounding area in September 2013. A total of 44 sites were checked for the presence of A. fluviatilis, which was found in 36 of these sites (see Table A1 for coordinates). The three main catchments (Tordera, Besòs, Ter) and an altitudinal gradient from 120 to 1295 masl (Fig. 1b) were covered by the sampling. A. fluviatilis specimens were collected by hand picking specimens from stones in the streams. All specimens were immediately stored in $70 \%$ ethanol, later transferred to $96 \%$ ethanol and stored at $4{ }^{\circ} \mathrm{C}$ until further analysis.

A sampling permit for protected areas (Parque Natural del Montseny) was obtained from the park management prior to sampling.

\section{DNA extraction, amplification and sequencing}

DNA was extracted from muscle tissue of 180 specimens (5 per site, 36 sampling sites) using a salt extraction protocol (Weiss \& Leese, 2016; modified from Sunnucks and Hales, 1996) (Overview of the samples: Table A1). A $658 \mathrm{bp}$-fragment of the barcoding gene COI was amplified using the primers LCO1490 and HCO2198 (Folmer et al., 1994). The polymerase chain reaction (PCR) mix was prepared using the following protocol: $1 \times$ PCR buffer, $0.2 \mathrm{mM}$ dNTPs, $1 \mu \mathrm{L}$ of DNA template, $0.025 \mathrm{U}_{.} \mu \mathrm{L}^{-1}$ Hotmaster Taq (5 PRIME GmbH, Hilden, Germany) and $0.5 \mu \mathrm{M}$ of each primer. The mix was filled up to $25 \mu \mathrm{L}$ with sterile $\mathrm{H}_{2} \mathrm{O}$ and placed in a thermocycler for amplification. PCR settings for the COI amplification were: initial denaturation at $94^{\circ} \mathrm{C}$ for $2 \mathrm{~min}$; 36 cycles of denaturation at $94{ }^{\circ} \mathrm{C}$ for $20 \mathrm{~s}$, annealing at $46^{\circ} \mathrm{C}$ for $30 \mathrm{~s}$, extension at $65^{\circ} \mathrm{C}$ for $60 \mathrm{~s}$; final extension at $65^{\circ} \mathrm{C}$ for $5 \mathrm{~min}$. Further, $9 \mu \mathrm{L}$ of the PCR product were purified enzymatically with $10 \mathrm{U}$ of Exonuclease I and $1 \mathrm{U}$ Shrimp Alkaline Phosphatase (Thermo Fisher Scientific, Waltham) by incubating at $37^{\circ} \mathrm{C}$ for $25 \mathrm{~min}$ and a denaturation step at $80^{\circ} \mathrm{C}$ for $15 \mathrm{~min}$. Bidirectional sequencing was performed on an ABI 3730 sequencer by GATC Biotech (Constance, Germany).

\section{Species delimitation}

Raw reads were assembled and edited using Geneious 6.0.5 (Biomatters). The MAFFT plugin (v. 7.017, Katoh 


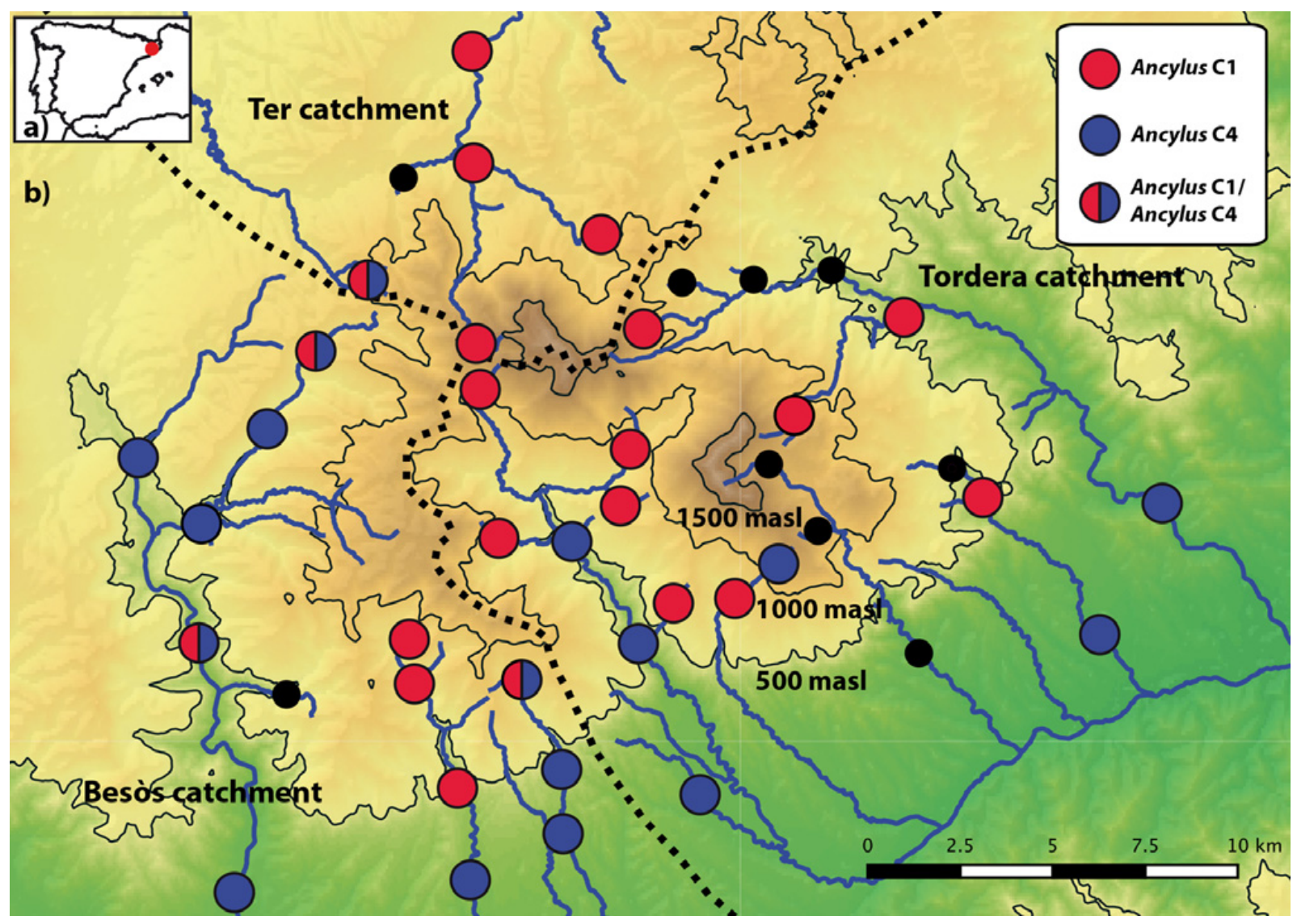

Fig. 1. (a) Location of the Montseny mountain range on the Iberian Peninsula (red circle); (b) map showing the occurrence of Ancylus fluviatilis Clade 1 and Clade 4 in the Montseny. Red dots indicate presence of A.fluviatilis $\mathrm{C} 1$, blue dots presence of A. fluviatilis $\mathrm{C} 4$. Mixed blue and red dots indicate the presence of both species at one sampling site. Black dots indicate absence of Ancylus fluviatilis. Catchment boundaries are shown as dashed black lines. Rivers are shown as blue lines.

and Standley, 2013) in Geneious was used to compute a multiple sequence alignment (automatic algorithm selection, default settings). The final length of the cropped alignments was $655 \mathrm{bp}$. The alignment was translated into amino acids using translation table 5 (invertebrate mitochondrial codon usage table) to make sure that no stop codons were present. The best model of evolution for further analyses of the data was selected with jModeltest 2.1.2 (Darriba et al., 2012) (default settings). Fabox (Villesen, 2007) was used to collapse sequences into haplotypes. PopART (v.1, Leigh and Bryant, 2015) was used to create statistical parsimony haplotype networks (Clement et al., 2000) with a $95 \%$ connection limit.

Two approaches were used to test for the presence of cryptic species in Ancylus fluviatilis sensu lato: first, the tree-based Generalized Mixed Yule Coalescent (GMYC) approach (Pons et al., 2006) and second, the automated distance-based barcode gap determination approach (ABGD, Puillandre et al., 2012). An ultrametric tree for all unique COI haplotypes was calculated for the GMYC analyses using BEAST v.1.8.0 (Drummond et al., 2012). BEAST was run for 10 million MCMC generations, sampling every 100 th tree and using both standard coalescent and the GTR $+\mathrm{G}$ sequence evolution model. Tracer v.1.6 (Rambaut et al., 2013) was used to test for effective sampling size (ESS) and convergence of parameters. TreeAnnotator v.1.8 (Rambaut and Drummond, 2013) was used to generate a linearized consensus tree, discarding the first 3000 trees as burn-in. R v. 3.1.1 (R Core Team, 2015) was used for analysis of the resulting tree with 'SPLITS' (Species Limit by Threshold Statistics) (Ezard et al., 2009) with the single threshold model to test for the presence of multiple species within the dataset. The second approach used for species delimitation was ABGD. Default settings were used, with Pmax $=0.1$ and the K2P-model of distance correction (Kimura, 1980), as this is the common approach in DNA barcoding studies. Once the number of genetic clades within the dataset was determined, specimens from each group were blasted against the Barcode of Life database (Ratnasingham and Hebert, 2007) to verify species assignment. The A. fluviatilis sequences from Pfenninger et al. (2003, accession numbers AY350509 - AY350525) were downloaded and aligned with the sequences generated in this study to verify assignment of sequences to one of the known cryptic species. Alignments for each species were created with Geneious and networks were computed with popArt as described above. QGIS (v 2.8, available from www.qgis.org) was used to create distribution maps. 


\section{Bioclimatic variables analyses}

The bioclimatic preferences of species were modelled using a maximum entropy method in MaxEnt 3.3.3e (Phillips and Dudík, 2008), which has been shown to work well with small sample sizes (Pearson et al., 2007). The region modelled was part of the North East Iberian Peninsula (area between coordinates $42^{\circ} 18^{\prime} \mathrm{N}, 1^{\circ} 48^{\prime} \mathrm{E}$, $41^{\circ} 06^{\prime} \mathrm{N}, 3^{\circ} 00^{\prime} \mathrm{E}$; WGS84). A total of 19 climate layers in the 30 arc-seconds grid were obtained from WorldClim (Hijmans et al., 2005) and resampled to a cell size of $800 \times 800 \mathrm{~m}^{2}$. WorldClim datasets are based upon standard meteorological precipitation and temperature measurements, which are transformed into bioclimatic variables (Hijmans et al., 2005). These datasets are commonly used as predictor variables in species distribution modelling. To avoid using highly non-independent variables in the analyses and thus omit overfitting of models, a Spearman's rank correlation tests was performed across all pairs of variables using ENMtools (Warren et al., 2010) and R ( R Core Team 2015). The correlation coefficient values used as thresholds beyond which values were treated as independent were 0.7, 0.8 and 0.9. All species presence points were used to build the model; $25 \%$ of the presence points were retained for training the model. All models were run 10 times with random partitioning of training and validation points. The accuracy of all computed models was evaluated with the area under receiver operation characteristic curve, which was also used to choose models for use in further analyses (Boubli and De, 2009). Range overlap and bioclimatic niche overlap were computed by using Schoener's D statistics as implemented in ENMtools. The values range from 0 (meaning no bioclimatic niche overlap) to 1 (identical range and bioclimatic niche, respectively).

\section{Geographic partitioning of genetic variation}

$\Phi_{\text {ST }}$ values as an indicator of population subdivision were calculated separately for all species found in the A. fluviatilis species complex using Arlequin software (v. 3.11, Excoffier et al., 2005). $\Phi_{\mathrm{ST}}$ was chosen since it takes population history (number of mutations between haplotypes) into account. For analyses of population differentiation between altitude zones, populations of all species were classed in three groups: $<500,500-1000$ and $>1000$ masl as in Múrria et al. (2014). For analyses of population differentiation between catchments, populations were classed as belonging to one of the three catchments (Tordera, Besòs, Ter) and $\Phi_{\mathrm{ST}}$ values between groups were calculated. The Bayesian Clustering software GENELAND (v.4.0.5 as implemented in R; Guillot et al., 2005) was used to further analyse population structure in the found $A$. fluviatilis species. Fabox was used to extract variable sites from alignments of the found species and PGDSpider (Excoffier and Lischer, 2010) was used to convert these alignments files into the GENELAND format. The settings used for running GENELAND were: five independent runs with a maximum of 10 populations, 300 nuclei, 10 million iterations, thinning interval of 10000 , resulting in 1000 retained trees. The first 200 trees were discarded as burn-in.

\section{Results}

\section{Molecular species delimitation}

Ancylus was found in 36 out of 44 sampled sites (Fig. 1b, see Table A1 for coordinates). A total of 180 specimens were analysed for the COI barcoding gene. The 655 bp alignment had $54(9.2 \%)$ variable sites and a GC content of $29.6 \%$. The null model of a single species was rejected both with the GMYC (likelihood ratio for single threshold model: $31.68, P<0.001)$ and the ABGD approach (Pmax 0.1\%). Both ABGD and GMYC suggested the presence of two groups in A. fluviatilis sensu lato. Blast searches against the Barcode of Life database assigned all sequences of both molecularly identified clades to either A. fluviatilis Clade 1 or A. fluviatilis Clade 4, both submitted by Pfenninger et al. (2003). Alignment of the generated sequences with those obtained from Genbank clustered 102 specimens with $A$. fluviatilis Clade 1, while 78 sequences clustered with $A$. fluviatilis Clade 4 . Both clades were defined by Pfenninger et al. (2003). Clade 1 corresponds to $A$. fluviatilis sensu stricto, while Clade 4 is a yet undescribed species with circum-Mediterranean distribution (Pfenninger et al., 2003). The maximum genetic distance between specimens clustering with $A$. fluviatilis Clade 1 was found to be $0.5 \%$. The minimum distance of A. fluviatilis specimens from the Montseny to specimens of A. fluviatilis Clade 1 from Pfenninger et al. (2003) was $0.3 \%$, while the maximum distance was $3.1 \%$. The minimum genetic distance between specimens of $A$. fluviatilis Clade 4 from the Montseny to those from Pfenninger et al. (2003) was $2.4 \%$, while the maximum distance was $2.7 \%$. The maximum genetic distance between the two clades found in the Montseny was 7.8\% (all uncorrected pairwise distances). The identified molecular clades are referred to as Ancylus $\mathrm{C} 1$ and Ancylus C4.

\section{Bioclimatic characterization}

For the modelling approach based on the 19 bioclimatic variables obtained from WorldClim, 3, 6 and 10 variables were retained after Spearman's Rank Correlation tests with thresholds of $0.7,0.8$ and 0.9 , respectively. The 6 variable model with a Spearman's Rank Correlation threshold of 0.8 resulted in good area under the receiver operating characteristic curve (AUC) values for both species (Ancylus C1: 0.96, Ancylus C4: 0.89), thus this model was chosen for all further analyses to mediate between lower variable correlation and higher model fitting (see Table A2 for all AUC values and variables). The best explaining bioclimatic variables for the occurrence of Ancylus C1 were the variables bio7 ("Temperature 
Annual Range") and bio19 ("Precipitation of Coldest Quarter"). Occurrence of Ancylus C4 was best predicted by the variables bio7 ("Temperature Annual Range") and bio15 ("Precipitation Seasonality") (Table A2). Bioclimatic niche overlap for Ancylus $\mathrm{C} 1$ and Ancylus $\mathrm{C} 4$ was 0.643 , the range overlap computed for occurrence likelihoods of $>50 \%$ was 0.728 (Table A3).

\section{Geographic partitioning of genetic variation within Ancylus species}

Both Ancylus C1 and Ancylus C4 were found in all three studied catchments of the Montseny. Ancylus $\mathrm{C} 1$ was found at 22 sampling sites and Ancylus $\mathrm{C} 4$ at 17 sampling sites. Both species occurred in syntopy at 4 sampling sites $(11.43 \%$; < 500 masl zone: 1 site, 500-1000 masl zone: 2 sites, > 1000 masl zone: 1 site; Fig. 2b). Ancylus $\mathrm{C} 1$ was found more often at higher altitude sites (332-1295 masl, median 665 masl) than Ancylus C4, which was more often found at lower altitude sites (120-1172 masl, median 440 masl).

Ancylus $\mathrm{C} 1$ showed significant population differentiation between the Tordera and Besòs $\left(\Phi_{\mathrm{ST}}\right.$ : 0.322, $P=0.00001)$ and the Tordera and Ter catchment $\left(\Phi_{\mathrm{ST}}\right.$ : $0.167, P=0.0001$ ) (Table A4). The most common haplotype ( $\left.\mathrm{HC}_{1}{ }_{1}\right)$ was found at 14 sites and in all three catchments (Tordera: 5 sites, Besòs: 4 sites, Ter: 5 sites) (Fig. 2a). $\mathrm{HCl}_{2} 2$ was found at 5 sites, of which 4 are located in the Tordera catchment and 1 in the Ter catchment. $\mathrm{HCl}_{-} 3$ was found at 9 sites and all three catchments (Tordera: $\overline{6}$ sites, Besòs: 2 sites, Ter: 1 site). Haplotypes $\mathrm{C} 1 \_4, \mathrm{C} 1 \_5, \mathrm{C} 1 \_6, \mathrm{C} 1 \_7$ and $\mathrm{C} 1 \_8$ were found in a maximum of two specimens each and at single sampling sites only. Significant population differentiation in Ancylus $\mathrm{C} 1$ was also found between the altitude zones $<500$ and $>1000$ masl $\left(\Phi_{\mathrm{ST}}: 0.343, P=0.00001\right)$ and between $500-1000$ and $>1000$ masl $\left(\Phi_{\mathrm{ST}}: 0.274, P=0.0001\right)$ (Table A4). GENELAND found three geographically defined groups in Ancylus C1. Group 1 contains the sampling sites dominated by $\mathrm{HC}_{-} \_$, mainly lying above 1000 masl (4 out of 5 sites). Group 2 contains sampling sites mainly dominated by HC1_1 (Populations in all altitude zones, but mainly ( 9 sites) in the 500-1000 masl zone). Group 3 contains sampling sites mainly dominated by HC1_3 (500-1000 masl zone: 5 sites; $<500$ masl zones: 3 sites) (Fig. 2a). A maximum of three substitutions were found between haplotypes of Ancylus C1 (Fig. 2b).

Ancylus C4 showed significant population differentiation between the Tordera and Besòs $\left(\Phi_{\mathrm{ST}}\right.$ : 0.408, $P=0.0001)$ and the Besòs and Ter catchments $\left(\Phi_{\mathrm{ST}}: 0.876\right.$, $P=0.00001)$, respectively. The most common haplotype (HC4_3) was found at 13 sampling sites (Besòs catchment: 9 sites, Tordera catchment: 4 sites). The second most common haplotype (HC4_1) was found in all three catchments (Tordera catchment: 4 sites, Ter catchment: 1 sites, Besòs catchment: 1 site). The haplotypes C4_2, C4_4 and C4 5 were found at single sites and in single specimens only (Fig. 2c). In Ancylus C4, significant population differentiation was found between populations in the $<500$ masl and the $500-1000$ masl zone $\left(\Phi_{\mathrm{ST}}: 0.335\right.$, $P=0.009)$ as well as between the $<500$ and $>1000$ masl zone $\left(\Phi_{\mathrm{ST}}: 0.667, P=0.00001\right)$. GENELAND found two geographically defined groups in Ancylus C4. Group 1 contains four sampling sites located in the northern and eastern parts of the study area, mainly dominated by haplotype C4_1 ( > 1000 masl zone: 2 sites, < 500 masl zone: 2 sites). Group 2 contains 13 sampling sites in the mid and western part of the Montseny, mainly dominated by haplotype C4_3 ( $<500$ masl zone: 10 sites, 500-1000 masl zone: 3 sites) (Fig. 2c). A maximum of two substitutions were found between haplotypes of Ancylus C4 (Fig. 2d).

\section{Discussion}

In this study, we investigated the number and distribution of A. fluviatilis sensu lato in the Montseny mountain range on the Iberian Peninsula. Our first expectation was that cryptic species of $A$. fluviatilis sensu lato are present in the study area. This expectation was met by the discovery of two molecular clades occurring in the Montseny. Both A. fluviatilis clades were initially delimited by Pfenninger et al. (2003). While Ancylus $\mathrm{C} 1$ corresponds to A. fluviatilis sensu stricto, Ancylus $\mathrm{C} 4$ is a yet undescribed species with a Mediterranean distribution, ranging from Portugal through the Southern Iberian Peninsula to Italy (Pfenninger et al., 2003; Albrecht et al., 2006). Although the distribution and ecology of cryptic species within A. fluviatilis sensu lato are roughly known on a European scale, our study is the first that allows assessment of the differences regarding small-scale distribution, population structure and bioclimatic preferences of two of them in the same region, allowing for a better understanding of species ecology. In the future, this might help with identification of species and improving stream quality assessments by making it possible to assign correct ecological traits to species.

Our second expectation was that different clades within A. Aluviatilis sensu lato rarely occur in syntopy, due to possibly different ecological demands or competition. Our results show that this might be true, as Ancylus $\mathrm{C} 1$ and Ancylus C4 occurred in syntopy in only $11.43 \%$ of the sites and showed altitudinal partitioning: Ancylus $\mathrm{C} 1$ was found more often at higher altitudes (median 665 masl), while Ancylus $\mathrm{C} 4$ was found more often at lower elevations (median 440 masl). Elevation is a good indicator for bioclimatic and environmental conditions such as temperature $\left(-0.65^{\circ} \mathrm{C}\right.$ per $100 \mathrm{~m}$ increase in altitude on average; Dodson and Marks, 1997) and flow velocity (due to steeper mountain slopes at higher altitudes). Thus, the observed pattern might hint at different bioclimatic preferences of the two species. However, due to the limited number of samples and the fact that both clades share $71 \%$ of the altitudinal range, it cannot be excluded that the pattern observed is mainly due to the limited sampling. The MaxEnt modelling approach results support the observed pattern, which suggests that Ancylus $\mathrm{C} 1$ occurs 


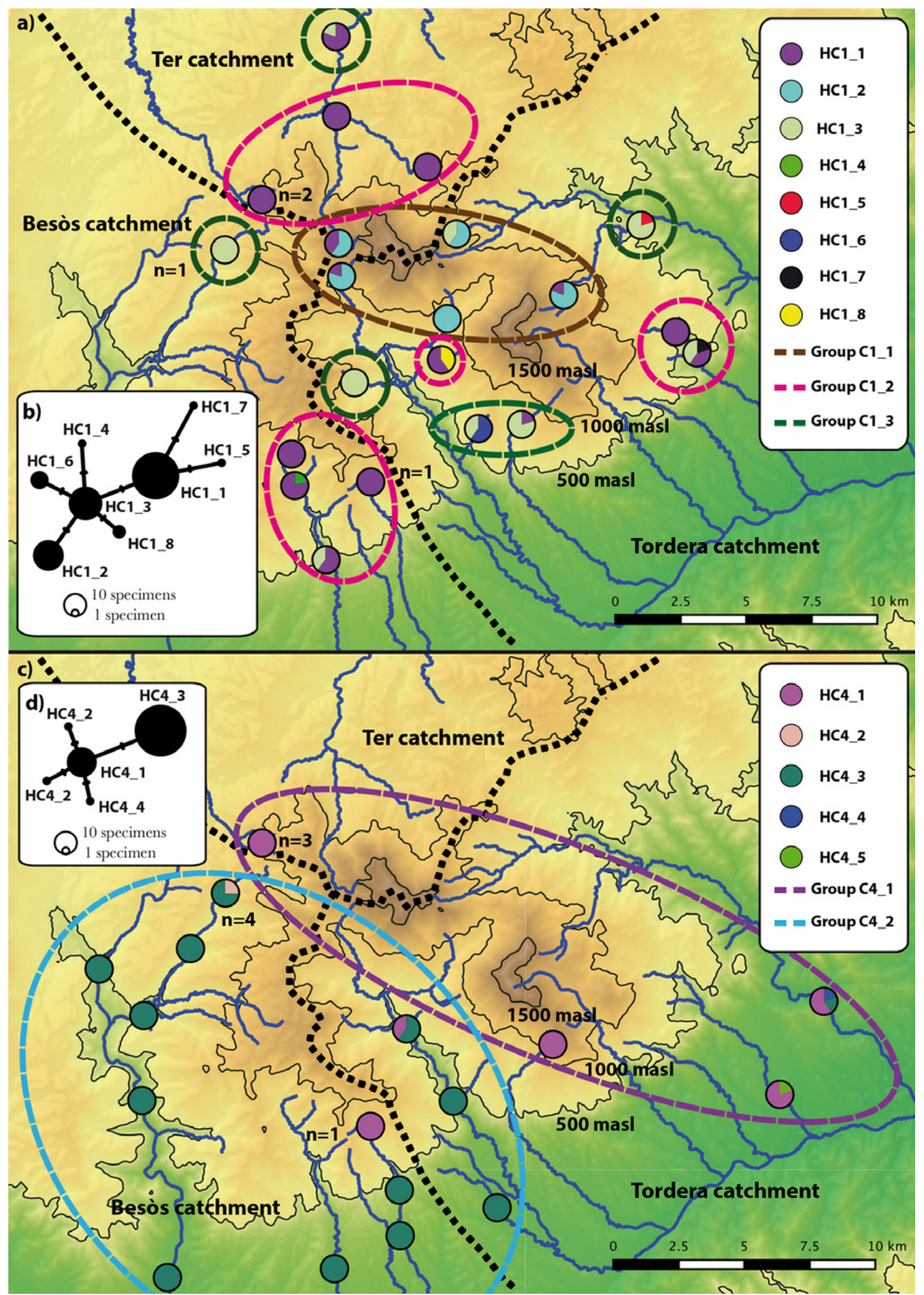

Fig. 2. (a) + (c) Map of the study area indicating the number of studied Ancylus fluviatilis specimens per sampling site and haplotypes found. Number of specimens per sampling site is 5, unless stated otherwise. GENELAND groups are shown as coloured dashed lines and catchment boundaries as black dashed lines. (b) +(d) Statistical Parsimony Network of A. fluviatilis Clade 1 and A. fluviatilis Clade 4 haplotypes, respectively. Dots represent sampled haplotypes, bars represent number of substitutions between haplotypes. 
in areas with lower mean annual temperature and strong precipitation during the cooler season of the year, while Ancylus C4 occurs in areas with strong precipitation seasonality and higher mean annual temperature. These findings correspond to those of Pfenninger et al. (2003) who, on a European scale, found Ancylus C1 to mainly inhabit cooler, precipitation-rich areas and Ancylus $\mathrm{C} 4$ to mainly inhabit hotter, seasonally drier areas. Similar patterns have been observed in other aquatic invertebrate species (e.g. Monaghan et al., 2005; Múrria et al., 2014). Closely related species co-occurring in the same area often inhabit different habitats due to different bioclimatic preferences or the competition exclusion principle (e.g. Fišer et al., 2015). In southern Europe, cooler and precipitation-rich conditions are mainly found at higher elevations, suggesting that Ancylus $\mathrm{Cl}$ might be close to the southern border of its distribution range in the Montseny. For aquatic species, higher precipitation means that more water is available during at least parts of the year, which is especially important in generally dry areas or areas with high precipitation seasonality. It appears thus possible that Ancylus $\mathrm{C} 1$ relies more on constant flow in the streams it inhabits, while Ancylus $\mathrm{C} 4$ might be able to cope with intermittent conditions in streams and generally higher water temperatures in lowland streams. This is especially important in the light of future climate change and ongoing human activities such as water abstraction, which might greatly alter temperature and precipitation patterns, ultimately changing flow regimes and thus possibly driving some species into local extinction while giving other species the possibility to colonize new habitats. Knowing the number and ecology of species in an area allows tracking the impact of such changes and preventing the loss of species. Tests of genetic differentiation, albeit based on a limited number of specimens and on the mitochondrial, maternally inherited COI gene only, hint at both A. fluviatilis clades found in the Montseny showing a division into lower altitude and higher altitude populations that differ genetically. Ancylus $\mathrm{C} 1$ populations from above 1000 masl significantly differed from populations below 1000 masl, which was also confirmed by the GENELAND analyses. Ancylus $\mathrm{C} 4$ populations from below 500 masl differed significantly from populations located above that altitude, likely due to the fact that the common haplotype C4_3 was found mainly below 500 masl. GENELAND, however, did not confirm the existence of a haplotype group corresponding with altitude in Ancylus C4, probably due to the low number of specimens from above 500 masl sampling sites. Although the limited amount of data per catchment and altitudinal zone does not allow us to draw definite conclusions, a pattern of genetic differentiation between higher-altitude and lower-altitude populations could hint at two phenomena, possibly in combination: one possibility is that specimens of A. fluviatilis sensu lato are weak dispersers that rarely migrate over longer distances within and between streams; thus over time, populations diverge genetically due to limited gene flow. Weak dispersal capabilities have been found in other freshwater gastropods (Kappes and
Haase, 2012). However, at least A. fluviatilis sensu stricto has been shown to disperse over longer distances (Cordellier and Pfenninger, 2008), e.g. via passive transport (Rees, 1965). The second explanation could be that populations from higher and lower altitudes differ genetically due to selective processes, having adapted to the different bioclimatic conditions. This corresponds to findings of other studies that found high-altitude populations of species to be genetically differentiated and potentially adapted to harsher bioclimatic conditions (e.g. McCulloch et al., 2009; Dussex et al., 2016). Fast adaptation to bioclimatic conditions has been found in Ancylus C1 (A. Aluviatilis sensu stricto) (Cordellier and Pfenninger, 2008), possibly making this explanation for the pattern observed in the Montseny more likely. Further studies based on nuclear markers and addressing the ecologies of both species need to be conducted, ideally using a combination of laboratory and field experiments. Overall, it remains possible that the patterns observed are mainly due to generally low genetic variation within the species and the relatively low number of sequenced specimens. The data are based on a limited number of specimens only and need to be interpreted with care. Studies involving nuclear markers and possibly a greater number of specimens per site are needed to verify the observed patterns of genetic variation on a geographically small scale. However, the patterns of population differentiation between altitudinal zones and catchments demonstrate the need to take population structure into account when planning to protect species and ecosystems. Environmental changes in the lower or higher altitude zones or in catchments might lead to the extinction of genotypes adapted to the local conditions. The resulting lower levels of genetic diversity possibly limit the adaptive potential of species and their ability to respond to environmental changes, ultimately leading to loss of genetic diversity in the species as a whole and increasing the risk of extinction (Bálint et al., 2011). Our study highlights the importance and potential of using molecular techniques to study species diversity and genetic diversity of species. Molecular studies can greatly help to understand the impact of climate change and other human stressors on biodiversity (Bálint et al., 2011; Hampe and Jump, 2011; Pauls et al., 2013; Macher et al., 2016). Here, we confirmed the occurrence of the two previously discovered potential cryptic species within a common freshwater taxon and genetic divergence within species on a small geographic scale. Our results show that patterns of genetic diversity, connectivity and bioclimatic preferences can be different even between closely related species, a fact that should be considered in biomonitoring and conservation plans. Knowledge of freshwater species diversity and ecological preferences is also important due to the fact that many bioassessment and monitoring programs worldwide rely on species occurrence data as a metric to measure ecosystem quality (e.g. Carter and Resh, 2001; Stark 2001; Haase et al., 2004) and the indication value of species is mostly derived from their ecological demands. Generally, not considering 
molecular data and cryptic species ecologies in monitoring programs can lead to strongly biased assessment results and ultimately to unsuitable management plans. The latter is especially problematic as management programmes often need to focus on protecting the maximum amount of biodiversity with the least amount of monetary effort. Using molecular methods can help to identify and effectively protect species and intraspecific diversity.

Acknowledgements. We thank Nuria Bonada for help in acquiring sampling permission for the Parque Natural Montseny and helpful discussions. The Parque Natural Montseny is thanked for giving us permission to collect samples in the park. We thank Alexander M. Weigand for helpful discussions and Lisa Poettker for help with sampling and lab work. We are indebted to the North-Rhine Westphalian Academy of Sciences for financial support.

\section{Data accessibility}

CO1 DNA sequences:

GenBank accession numbers for Ancylus Clade 1: KY012061-KY012162. Will be available upon publication and numbers will be added accordingly.

GenBank accession numbers for Ancylus Clade 4: KY012163-KY012240.

\section{Conflict of Interest}

None to declare.

\section{References}

Adams M., Raadik T., Burridge C. and Georges A., 2014. Global biodiversity assessment and hyper-cryptic species complexes: more than one species of elephant in the room? Syst. Biol, 63, $518-533$.

Albrecht C., Trajanovski S., Kuhn K., Streit B. and Wilke T., 2006. Rapid evolution of an ancient lake species flock: freshwater limpets (Gastropoda: Ancylidae) in the Balkan Lake Ohrid. Org. Divers Evol., 6, 294-307.

Amato A., Kooistra W., Ghiron J., Mann D., Pröschold T. and Montresor M., 2007. Reproductive isolation among sympatric cryptic species in marine diatoms. Protist, 158, 193-207.

Bálint M., Domisch S., Engelhardt C., Haase P., Lehrian S., Sauer J., Theissinger K., Pauls S. and Nowak C., 2011. Cryptic biodiversity loss linked to global climate change. Nat. Clim. Change, 1, 313-318.

Boag D., 1986. Dispersal in pond snails: potential role of waterfowl. Can. J. Zool., 64, 904-909.

Bonin A., Taberlet P., Miaud C. and Pompanon F., 2006. Explorative genome scan to detect candidate loci for adaptation along a gradient of altitude in the common frog (Rana temporaria). Mol. Biol. Evol. 23, 773-783.
Boubli J. and De L., 2009. Modeling the geographical distribution and fundamental niches of Cacajao spp. and Chiropotes israelita in Northwestern Amazonia via a maximum entropy algorithm. Int. J. Primatol., 30, 217-228.

Carter J. and Resh V., 2001. After site selection and before data analysis: sampling, sorting, and laboratory procedures used in stream benthic macroinvertebrate monitoring programs by USA state agencies. J. N. Am. Benthol. Soc., 20, 658-682.

Cauvy-Fraunié S., Espinosa R., Andino P., Jacobsen D. and Dangles O., 2015. Invertebrate metacommunity structure and dynamics in an Andean glacial stream network facing climate change. PLoS ONE, 10, e0136793.

Clement M., Posada D. and Crandall K., 2000. TCS: a computer program to estimate gene genealogies. Mol. Ecol., 9, 1657-1659.

Cordellier M. and Pfenninger M., 2008. Climate-driven range dynamics of the freshwater limpet, Ancylus fluviatilis (Pulmonata, Basommatophora). J. Biogeogr., 35, 1580-1592.

Darriba D., Taboada G., Doallo R. and Posada D., 2012. jModelTest 2: more models, new heuristics and parallel computing. Nat. Methods, 9, 772.

Dodson R. and Marks D., 1997. Daily air temperature interpolated at high spatial resolution over a large mountainous region. Clim. Res., 8, 1-20.

Drummond A., Suchard M., Xie D. and Rambaut A., 2012. Bayesian phylogenetics with BEAUti and the BEAST 1.7. Mol. Biol. Evol., 29, 1969-1973.

Dussex N., Chuah A. and Waters J., 2016. Genome-wide SNPs reveal fine-scale differentiation among wingless alpine stonefly populations and introgression between winged and wingless forms. Evolution, 70, 38-47.

Excoffier L. and Lischer H., 2010. Arlequin suite ver 3.5: a new series of programs to perform population genetics analyses under Linux and Windows. Mol. Ecol. Resour., 10, 564-567.

Excoffier L., Laval G. and Schneider S., 2005. Arlequin (version 3.0): an integrated software package for population genetics data analysis. Evol. Bioinform. Online, 1, 47-50.

Ezard T., Fujisawa T. and Barraclough T., 2009. SPLITS: species' limits by threshold statistics. R Package Version 1.

Figuerola J. and Green A., 2002. Dispersal of aquatic organisms by waterbirds a review of past research and priorities for future studies. Freshw. Biol., 47, 483-494.

Finn D. and Poff L., 2005. Variability and convergence in benthic communities along the longitudinal gradients of four physically similar Rocky Mountain streams. Freshw. Biol., 50, 243-261.

Fišer Z., Altermatt F., Zakšek V., Knapič T. and Fišer C., 2015. Morphologically cryptic amphipod species are "ecological clones" at regional but not at local scale: a case study of four niphargus species. PLoS ONE, 10, e0134384.

Folmer O., Black M., Hoeh W., Lutz R. and Vrijenhoek R., 1994. DNA primers for amplification of mitochondrial cytochrome c oxidase subunit I from diverse metazoan invertebrates. Mol. Mar. Biol. Biotechnol., 3, 294-299.

Guillot G., Mortier F. and Estoup A., 2005. Geneland: a computer package for landscape genetics. Mol. Ecol. Notes, $5,712-715$.

Haase P., Lohse S., Pauls S., Schindehütte K., Sundermann A., Rolauffs P. and Hering D., 2004. Assessing streams in Germany with benthic invertebrates: development of a practical standardised protocol for macroinvertebrate 
sampling and sorting. Limnol.-Ecol. Manag. Inland Waters, 34, 349-365.

Hampe A. and Jump A., 2011. Climate relicts: past, present, future. Annu. Rev. Ecol. Evol. Syst., 42, 313-333.

Haun T., Salinger M., Pachzelt A. and Pfenninger M., 2012. On the processes shaping small-scale population structure in Radix balthica (Linnaeus 1758). Malacologia, 55, 219-233.

Hijmans R., Cameron S., Parra J., Jones P. and Jarvis A., 2005. Very high resolution interpolated climate surfaces for global land areas. Int. J. Climatol., 25, 1965-1978.

Hubendick B., 1970. Studies on Ancylidae: The palearctic and oriental species and form groups. Acta R. Soc. Scient. Litt. Gothoburg, 5, 1-52.

Jump A., Hunt J. and Penuelas J., 2007. Climate relationships of growth and establishment across the altitudinal range of Fagus sylvatica in the Montseny Mountains, northeast Spain. Ecoscience, 14, 507-518.

Kappes H. and Haase P., 2012. Slow, but steady: dispersal of freshwater molluscs. Aquat. Sci., 74, 1.

Katoh K. and Standley D., 2013. MAFFT multiple sequence alignment software version 7: improvements in performance and usability. Mol. Biol. Evol., 30, 772-780.

Katouzian A., Sari A., Macher J., Weiss M., Saboori A., Leese F. and Weigand A., 2016. Drastic underestimation of amphipod biodiversity in the endangered Irano-Anatolian and Caucasus biodiversity hotspots. Sci. Rep., 6, 22507.

Keller I., Alexander J., Holderegger R. and Edwards P., 2013. Widespread phenotypic and genetic divergence along altitudinal gradients in animals. J. Evol. Biol., 26, 2527-2543.

Kimura M., 1980. A simple method for estimating evolutionary rates of base substitutions through comparative studies of nucleotide sequences. J. Mol. Evol., 16, 111-120.

Lagrue C., Wattier R., Galipaud M., Gauthey Z., Rullmann J., Dubreuil C., Rigaud T. and Bollache L., 2014. Confrontation of cryptic diversity and mate discrimination within Gammarus pulex and Gammarus fossarum species complexes. Freshw. Biol., 59, 2555-2570.

Leigh J. and Bryant D., 2015. Popart: full-feature software for haplotype network construction. Methods Ecol. Evol., 6, 1110-1116.

Liebherr J., 1986. Comparison of genetic variation in two carabid beetles (Coleoptera) of differing vagility. Ann. Entomol. Soc. Am., 79, 424-433.

Macher J., Salis R., Blakemore K., Tollrian R., Matthaei C. and Leese F., 2016. Multiple-stressor effects on stream invertebrates: DNA barcoding reveals contrasting responses of cryptic mayfly species. Ecol. Indic., 61, 159-169.

Mamos T., Wattier R., Burzyński A. and Grabowski M., 2016. The legacy of a vanished sea: a high level of diversification within a European freshwater amphipod species complex driven by 15 My of Paratethys regression. Mol. Ecol., 25, 795-810.

McCulloch G., Wallis G. and Waters J., 2009. Do insects lose flight before they lose their wings? Population genetic structure in subalpine stoneflies. Mol. Ecol., 18, 4073-4087.

Monaghan M., Robinson C., Spaak P. and Ward J., 2005. Macroinvertebrate diversity in fragmented Alpine streams: implications for freshwater conservation. Aquat. Sci., 67, 454-464.

Múrria C., Morante M., Rieradevall A., Ribera A. and Prat N., 2014. Genetic diversity and species richness patterns in
Baetidae (Ephemeroptera) in the Montseny Mountain range (North-East Iberian Peninsula). Limnetica, 33, 313-326.

Ortells R., Gómez A. and Serra M., 2003. Coexistence of cryptic rotifer species: ecological and genetic characterisation of Brachionus plicatilis. Freshw. Biol., 48, 2194-2202.

Pauls S., Theissinger K., Ujvarosi L., Balint M. and Haase P., 2009. Patterns of population structure in two closely related, partially sympatric caddisflies in Eastern Europe: historic introgression, limited dispersal, and cryptic diversity 1. J. N. Am. Benthol. Soc., 28, 517-536.

Pauls S., Blahnik R., Zhou X., Wardwell C. and Holzenthal R., 2010. DNA barcode data confirm new species and reveal cryptic diversity in Chilean Smicridea (Smicridea) (Trichoptera: Hydropsychidae). J. N. Am. Benthol. Soc., 29, 1058-1074.

Pauls S., Nowak C., Bálint M. and Pfenninger M., 2013. The impact of global climate change on genetic diversity within populations and species. Mol. Ecol., 22, 925-946.

Pearson R., Raxworthy C., Nakamura M. and Townsend P., 2007. Predicting species distributions from small numbers of occurrence records: a test case using cryptic geckos in Madagascar. J. Biogeogr., 34, 102-117.

Peñuelas J. and Boada M., 2003. A global change-induced biome shift in the Montseny mountains (NE Spain). Glob. Change Biol., 9, 131-140.

Pfenninger M. and Schwenk K., 2007. Cryptic animal species are homogeneously distributed among taxa and biogeographical regions. BMC Evol. Biol., 7, 121.

Pfenninger M., Staubach S., Albrecht C., Streit B. and Schwenk K., 2003. Ecological and morphological differentiation among cryptic evolutionary lineages in freshwater limpets of the nominal form-group Ancylus fluviatilis (O.F. Müller, 1774). Mol. Ecol., 12, 2731-2745.

Phillips S. and Dudík M., 2008. Modeling of species distributions with Maxent: new extensions and a comprehensive evaluation. Ecography, 31, 161-175.

Pons J., Barraclough T., Gomez-Zurita J., Cardoso A., Duran D., Hazell S., Kamoun S., Sumlin W. and Vogler A., 2006. Sequence-based species delimitation for the DNA taxonomy of undescribed insects. Syst. Biol., 55, 595-609.

Puillandre N., Lambert A., Brouillet S. and Achaz G., 2012. ABGD, Automatic Barcode Gap Discovery for primary species delimitation. Mol. Ecol., 21, 1864-1877.

Rambaut A. and Drummond A., 2013. TreeAnnotator v1. 7.0.

Rambaut A., Suchard M., Xie D. and Drummond A., 2013. Tracer v1.5, Available from http://beast.bio.ed.ac.uk/Tracer.

Ratnasingham S. and Hebert P., 2007. BOLD: the Barcode of Life Data System (http://www.barcodinglife.org). Mol. Ecol. Notes, 7, 355-364.

R Core Team, 2015. R: A language and environment for statistical computing. $\mathrm{R}$ Foundation for Statistical Computing, Vienna, Austria. URL http://www.R-project. org/.

Rees W., 1965. The aerial dispersal of Mollusca. J. Molluscan Stud., 36, 269-282.

Rissler L. and Apodaca J., 2007. Adding more ecology into species delimitation: ecological niche models and phylogeography help define cryptic species in the black salamander (Aneides flavipunctatus). Syst. Biol., 56, 924-942.

Segerstråle S., 1954. The Freshwater Amphipods, Gammarus Pulex (L.) and Gammarus Lacustris GO Sars, in Denmark and Fennoscandia - a Contribution to the Late - and 
Postglacial Immigration History of the Aquatic Fauna of Northern Europe. Soc. Si. Fenn. Comm. Biol., 15, 1-91.

Stark J.D., 2001. Protocols for Sampling Macroinvertebrates in Wadeable Streams, Cawthron Institute, New Zealand.

Steffen W., Richardson K., Rockström J., Cornell S., Fetzer I., Bennett E., Biggs R., Carpenter S., de Vries W. and de Wit C., 2015. Planetary boundaries: guiding human development on a changing planet. Science, 347, 1259855.

Sunnucks P. and Hales D., 1996. Numerous transposed sequences of mitochondrial cytochrome oxidase I-II in aphids of the genus Sitobion (Hemiptera: Aphididae). Mol. Biol. Evol., 13, 510-524.

Thuiller W., Vayreda J., Pino J., Sabate S., Lavorel S. and Gracia C., 2003. Large-scale environmental correlates of forest tree distributions in Catalonia (NE Spain). Glob. Ecol. Biogeogr., 12, 313-325.

Van Leeuwen C., Velde G., Groenendael J. and Klaassen M., 2012. Gut travellers: internal dispersal of aquatic organisms by waterfowl. J. Biogeogr., 39, 2031-2040.

Villesen P., 2007. FaBox: an online toolbox for fasta sequences. Mol. Ecol. Notes, 7, 965-968.

Vörösmarty C., McIntyre P., Gessner M., Dudgeon D., Prusevich A., Green P., Glidden S., Bunn S., Sullivan C.,
Reidy Liermann C. and Davies P., 2010. Global threats to human water security and river biodiversity. Nature, 467, 555-561.

Warren D., Glor R. and Turelli M., 2010. ENMTools: a toolbox for comparative studies of environmental niche models. Ecography, 33, 607-611.

Watanabe K., Kazama S., Omura T. and Monaghan M., 2014. Adaptive genetic divergence along narrow environmental gradients in four stream insects. PLoS ONE, 9, e93055.

Weigand A., Jochum A., Pfenninger MM, Steinke D. and Klussmann-Kolb A., 2011. A new approach to an old conundrum-DNA barcoding sheds new light on phenotypic plasticity and morphological stasis in microsnails (Gastropoda, Pulmonata, Carychiidae). Mol. Ecol. Resour., 11, 255-265.

Weiss M. and Leese F., 2016. Widely distributed and regionally isolated! Drivers of genetic structure in Gammarus fossarum in a human-impacted landscape. BMC Evol. Biol., doi: 10.1186/s12862-016-0723-z.

Weiss M., Macher J., Seefeldt M. and Leese F., 2014. Molecular evidence for further overlooked species within the Gammarus fossarum complex (Crustacea: Amphipoda). Hydrobiologia, $721,165-184$. 


\section{Appendix}

Table A1. Clade assignments, specimen IDs, sampling site IDs and sampling site coordinates (Lat/Long, WGS84) for Ancylus fluviatilis specimens from the Montseny.

\begin{tabular}{|c|c|c|c|c|}
\hline $\begin{array}{l}\text { Ancylus } \\
\text { fluviatilis } \\
\text { clade }\end{array}$ & $\begin{array}{c}\text { Specimen ID } \\
\text { Ancylus } \\
\text { fluviatilis }\end{array}$ & $\begin{array}{l}\text { Sampling } \\
\text { site ID }\end{array}$ & Latitude & Longitude \\
\hline 1 & A_Di04_1 & Di4 & 2.44 & 41.75 \\
\hline 1 & A_Di04_2 & Di4 & 2.44 & 41.75 \\
\hline 1 & A_Di04_3 & Di4 & 2.44 & 41.75 \\
\hline 1 & A_Di04_4 & Di4 & 2.44 & 41.75 \\
\hline 1 & A_Di04_5 & Di4 & 2.44 & 41.75 \\
\hline 1 & A Di05.1 1 & Di5.1 & 2.42 & 41.75 \\
\hline 1 & $\mathrm{~A}^{-} \mathrm{Di05.1}{ }^{-} 2$ & Di5.1 & 2.42 & 41.75 \\
\hline 1 & A_Di05.1_3 & Di5.1 & 2.42 & 41.75 \\
\hline 1 & A_Di05.1_4 & Di5.1 & 2.42 & 41.75 \\
\hline 1 & A_Di05.1_5 & Di5.1 & 2.42 & 41.75 \\
\hline 1 & A_Di08_1 & Di8 & 2.51 & 41.78 \\
\hline 1 & A_Di08_2 & Di8 & 2.51 & 41.78 \\
\hline 1 & A_Di08_3 & Di8 & 2.51 & 41.78 \\
\hline 1 & A_Di08_4 & Di8 & 2.51 & 41.78 \\
\hline 1 & A_Di08_5 & Di8 & 2.51 & 41.78 \\
\hline 1 & $\mathrm{~A}^{-} \mathrm{Di} 10-1$ & Di10 & 2.52 & 41.77 \\
\hline 1 & A_Di10_2 & Di10 & 2.52 & 41.77 \\
\hline 1 & A_Di10_3 & Di10 & 2.52 & 41.77 \\
\hline 1 & A_Di10_4 & Dil0 & 2.52 & 41.77 \\
\hline 1 & A_Di10_5 & Dil0 & 2.52 & 41.77 \\
\hline 1 & A_Do01_5 & Do1 & 2.3 & 41.81 \\
\hline 1 & A_DoH_1 & DoH & 2.4 & 41.77 \\
\hline 1 & A_DoH_2 & DoH & 2.4 & 41.77 \\
\hline 1 & A_DoH_3 & DoH & 2.4 & 41.77 \\
\hline 1 & A_DoH_4 & DoH & 2.4 & 41.77 \\
\hline 1 & $\mathrm{~A}^{-} \mathrm{DoH} 5$ & DoH & 2.4 & 41.77 \\
\hline 1 & A_Fr01_1 & Fr01 & 2.36 & 41.81 \\
\hline 1 & A_Fr01_2 & Fr01 & 2.36 & 41.81 \\
\hline 1 & A_Fr01_3 & Fr01 & 2.36 & 41.81 \\
\hline 1 & A_Fr01_4 & Fr01 & 2.36 & 41.81 \\
\hline 1 & A_Fr01_5 & Fr01 & 2.36 & 41.81 \\
\hline 1 & A_Fr02.1_3 & Fr2.1 & 2.32 & 41.83 \\
\hline 1 & A_Fr02.1_5 & Fr2.1 & 2.32 & 41.83 \\
\hline 1 & A_Fr04_1- & Fr4 & 2.36 & 41.85 \\
\hline 1 & A Fr04 2 & Fr4 & 2.36 & 41.85 \\
\hline 1 & $\mathrm{~A}^{-} \mathrm{Fr} 04^{-} 3$ & Fr4 & 2.36 & 41.85 \\
\hline 1 & A_Fr04_4 & Fr4 & 2.36 & 41.85 \\
\hline 1 & A_Fr04_5 & Fr4 & 2.36 & 41.85 \\
\hline 1 & A_Fr06_1 & Fr6 & 2.36 & 41.88 \\
\hline 1 & A_Fr06_2 & Fr6 & 2.36 & 41.88 \\
\hline 1 & A_Fr06_3 & Fr6 & 2.36 & 41.88 \\
\hline 1 & A_Fr06_4 & Fr6 & 2.36 & 41.88 \\
\hline 1 & A_Fr06_5 & Fr6 & 2.36 & 41.88 \\
\hline 1 & A_Fr07_1 & Fr7 & 2.38 & 41.9 \\
\hline 1 & $\mathrm{~A}^{-} \mathrm{Fr} 07^{-} 2$ & Fr7 & 2.38 & 41.9 \\
\hline 1 & A_Fr07_3_ & Fr7 & 2.38 & 41.9 \\
\hline 1 & A_Fr07_4 & Fr7 & 2.38 & 41.9 \\
\hline 1 & A_Fr07_5 & Fr7 & 2.38 & 41.9 \\
\hline 1 & A_Fr08_1 & Fr8 & 2.4 & 41.84 \\
\hline 1 & A_Fr08_2 & Fr8 & 2.4 & 41.84 \\
\hline 1 & A_Fr08_3 & Fr8 & 2.4 & 41.84 \\
\hline 1 & A_Fr08_4 & Fr8 & 2.4 & 41.84 \\
\hline 1 & A_Fr08_5 & Fr8 & 2.4 & 41.84 \\
\hline 1 & A_Fr09.1_1 & Fr9.1 & 2.46 & 41.79 \\
\hline 1 & $\mathrm{~A}^{-} \mathrm{Fr} 09.1-2$ & Fr9.1 & 2.46 & 41.79 \\
\hline 1 & A_Fr09.1_3 & Fr9.1 & 2.46 & 41.79 \\
\hline 1 & A_Fr09.1_4 & Fr9.1 & 2.46 & 41.79 \\
\hline 1 & A_Fr09.1_5 & Fr9.1 & 2.46 & 41.79 \\
\hline
\end{tabular}

Table A1. Continued

\begin{tabular}{|c|c|c|c|c|}
\hline $\begin{array}{l}\text { Ancylus } \\
\text { fluviatilis } \\
\text { clade }\end{array}$ & $\begin{array}{c}\text { Specimen ID } \\
\text { Ancylus } \\
\text { fluviatilis }\end{array}$ & $\begin{array}{l}\text { Sampling } \\
\text { site ID }\end{array}$ & Latitude & Longitude \\
\hline 1 & A_Fr09_1 & Fr09 & 2.41 & 41.81 \\
\hline 1 & A_Fr09_2 & Fr09 & 2.41 & 41.81 \\
\hline 1 & A_Fr09_3 & Fr09 & 2.41 & 41.81 \\
\hline 1 & $A^{-} \mathrm{Fr} 094$ & Fr09 & 2.41 & 41.81 \\
\hline 1 & A_Fr09_5 & Fr09 & 2.41 & 41.81 \\
\hline 1 & A_Mi05_1 & Mi5 & 2.37 & 41.73 \\
\hline 1 & A_Mi05_2 & Mi5 & 2.37 & 41.73 \\
\hline 1 & A_Mi05_3_- & Mi5 & 2.37 & 41.73 \\
\hline 1 & A_Mi05_4 & Mi5 & 2.37 & 41.73 \\
\hline 1 & A_Mi07_1 & Mi7 & 2.34 & 41.73 \\
\hline 1 & A_Mi07_2_ & Mi7 & 2.34 & 41.73 \\
\hline 1 & A_Mi07_3- & Mi7 & 2.34 & 41.73 \\
\hline 1 & $\mathrm{~A}_{-}^{-} \mathrm{Mi07}{ }^{-}{ }^{-}$ & Mi7 & 2.34 & 41.73 \\
\hline 1 & $\mathrm{~A}^{-} \mathrm{Mi} 07^{-} 5^{-}$ & Mi7 & 2.34 & 41.73 \\
\hline 1 & A_Mi08_1 & Mi8 & 2.34 & 41.74 \\
\hline 1 & A_Mi08_2 & Mi8 & 2.34 & 41.74 \\
\hline 1 & A_Mi08_3_ & Mi8 & 2.34 & 41.74 \\
\hline 1 & A_Mi08_4_- & Mi8 & 2.34 & 41.74 \\
\hline 1 & A_Mi08_5 & Mi8 & 2.34 & 41.74 \\
\hline 1 & A_Mi09_1 & Mi9 & 2.35 & 41.7 \\
\hline 1 & A_Mi09_2 & Mi9 & 2.35 & 41.7 \\
\hline 1 & A_Mi09_3 & Mi9 & 2.35 & 41.7 \\
\hline 1 & A_Mi09_4 & Mi9 & 2.35 & 41.7 \\
\hline 1 & $\mathrm{~A}^{-} \mathrm{Mi} 09^{-} 5$ & Mi9 & 2.35 & 41.7 \\
\hline 1 & A_Mo03_1 & Mo3 & 2.36 & 41.76 \\
\hline 1 & A_Mo03_2 & Mo3 & 2.36 & 41.76 \\
\hline 1 & A_Mo03_3 & Mo3 & 2.36 & 41.76 \\
\hline 1 & A_Mo03_4 & Mo3 & 2.36 & 41.76 \\
\hline 1 & A_Mo03_5 & Mo3 & 2.36 & 41.76 \\
\hline 1 & A_Mo06_1 & Mo6 & 2.36 & 41.8 \\
\hline 1 & A_Mo06_2 & Mo6 & 2.36 & 41.8 \\
\hline 1 & A_Mo06_3 & Mo6 & 2.36 & 41.8 \\
\hline 1 & A Mo064 & Mo6 & 2.36 & 41.8 \\
\hline 1 & A_Mo06_5 & Mo6 & 2.36 & 41.8 \\
\hline 1 & A_Mo07_1 & Mo7 & 2.41 & 41.78 \\
\hline 1 & A_Mo07_2 & Mo7 & 2.41 & 41.78 \\
\hline 1 & A_Mo07_3_ & Mo7 & 2.41 & 41.78 \\
\hline 1 & A_Mo07_4- & Mo7 & 2.41 & 41.78 \\
\hline 1 & A_Mo07_5 & Mo7 & 2.41 & 41.78 \\
\hline 1 & A_Sa04.1_1 & $\mathrm{Sa} 4.1$ & 2.5 & 41.82 \\
\hline 1 & A_Sa04.1_2 & $\mathrm{Sa} 4.1$ & 2.5 & 41.82 \\
\hline 1 & A_Sa04.1_3 & $\mathrm{Sa} 4.1$ & 2.5 & 41.82 \\
\hline 1 & A $\mathrm{Sa} 04.14$ & $\mathrm{Sa} 4.1$ & 2.5 & 41.82 \\
\hline 1 & A_Sa04.1_5 & $\mathrm{Sa} 4.1$ & 2.5 & 41.82 \\
\hline 4 & A_Di01_1 & Dil & 2.46 & 41.76 \\
\hline 4 & A_Di01_2 & Dil & 2.46 & 41.76 \\
\hline 4 & A_Di01_3 & Dil & 2.46 & 41.76 \\
\hline 4 & A_Di01_4 & Dil & 2.46 & 41.76 \\
\hline 4 & A_Di01_5 & Dil & 2.46 & 41.76 \\
\hline 4 & A_Di11_1 & Dil1 & 2.56 & 41.74 \\
\hline 4 & A_Dil1_2 & Dil1 & 2.56 & 41.74 \\
\hline 4 & A Dill 3 & Dil1 & 2.56 & 41.74 \\
\hline 4 & A Dill 4 & Dill & 2.56 & 41.74 \\
\hline 4 & A_Dil1_5 & Dil1 & 2.56 & 41.74 \\
\hline 4 & A_Do01_1 & Dol & 2.3 & 41.81 \\
\hline 4 & A_Do01_2 & Dol & 2.3 & 41.81 \\
\hline 4 & A_Do01_3 & Dol & 2.3 & 41.81 \\
\hline 4 & A_Do01_4 & Do1 & 2.3 & 41.81 \\
\hline 4 & A_Do02_1 & Do2 & 2.29 & 41.79 \\
\hline 4 & A_Do02_2 & Do2 & 2.29 & 41.79 \\
\hline
\end{tabular}


Table A1. Continued

\begin{tabular}{|c|c|c|c|c|}
\hline $\begin{array}{l}\text { Ancylus } \\
\text { fluviatilis } \\
\text { clade }\end{array}$ & $\begin{array}{c}\text { Specimen ID } \\
\text { Ancylus } \\
\text { fluviatilis }\end{array}$ & $\begin{array}{c}\text { Sampling } \\
\text { site ID }\end{array}$ & Latitude & Longitude \\
\hline 4 & A_Do02_3 & Do2 & 2.29 & 41.79 \\
\hline 4 & $\mathrm{~A}^{-} \mathrm{Do} 02^{-} 4$ & Do2 & 2.29 & 41.79 \\
\hline 4 & A_Do02_5 & Do2 & 2.29 & 41.79 \\
\hline 4 & A_Do03_1 & Do3 & 2.27 & 41.77 \\
\hline 4 & A_Do03_2 & Do3 & 2.27 & 41.77 \\
\hline 4 & A_Do03_3 & Do3 & 2.27 & 41.77 \\
\hline 4 & A_Do03_4 & Do3 & 2.27 & 41.77 \\
\hline 4 & A_Do03_5 & Do3 & 2.27 & 41.77 \\
\hline 4 & A_Do04.1_1 & Do4.1 & 2.27 & 41.74 \\
\hline 4 & A_Do04.1_2 & Do4.1 & 2.27 & 41.74 \\
\hline 4 & A_Do04.1_3 & Do4.1 & 2.27 & 41.74 \\
\hline 4 & A_Do04.1_4 & Do4.1 & 2.27 & 41.74 \\
\hline 4 & A_Do04.1_5 & Do4.1 & 2.27 & 41.74 \\
\hline 4 & A_Dol0_1- & Do10 & 2.28 & 41.68 \\
\hline 4 & A_Do10_2 & Do10 & 2.28 & 41.68 \\
\hline 4 & A_Do10_3 & Dol0 & 2.28 & 41.68 \\
\hline 4 & A_Do10_4 & Do10 & 2.28 & 41.68 \\
\hline 4 & A_Do10_5 & Do10 & 2.28 & 41.68 \\
\hline 4 & A_Do11_1 & Do11 & 2.25 & 41.78 \\
\hline 4 & A_Do11_2 & Do11 & 2.25 & 41.78 \\
\hline 4 & A_Do11_3 & Do11 & 2.25 & 41.78 \\
\hline 4 & A_Do11_4 & Do11 & 2.25 & 41.78 \\
\hline 4 & A_Do11_5 & Do11 & 2.25 & 41.78 \\
\hline 4 & A_Fr02.1. & Fr2.1 & 2.32 & 41.83 \\
\hline 4 & A_Fr02.1_2 & Fr2.1 & 2.32 & 41.83 \\
\hline 4 & A_Fr02.1_4 & Fr2.1 & 2.32 & 41.83 \\
\hline 4 & A_Mi03_-̄ & Mi3 & 2.38 & 41.71 \\
\hline 4 & A_Mi03_2 & Mi3 & 2.38 & 41.71 \\
\hline 4 & A_Mi03_3 & Mi3 & 2.38 & 41.71 \\
\hline 4 & A_Mi03_4 & Mi3 & 2.38 & 41.71 \\
\hline 4 & A_Mi03_5 & $\mathrm{Mi3}$ & 2.38 & 41.71 \\
\hline 4 & A_Mi05_5 & Mi5 & 2.37 & 41.73 \\
\hline 4 & A_Mi10_1 & Mil0 & 2.39 & 41.69 \\
\hline 4 & A_Mil0_2 & Mil0 & 2.39 & 41.69 \\
\hline 4 & A_Mi10_3 & Mil0 & 2.39 & 41.69 \\
\hline 4 & A_Mi10_4 & Mil0 & 2.39 & 41.69 \\
\hline 4 & A_Mi10_5 & Mil0 & 2.39 & 41.69 \\
\hline 4 & A_Mil1_1 & Mil1 & 2.36 & 41.68 \\
\hline 4 & A_Mil1_2 & Mil1 & 2.36 & 41.68 \\
\hline 4 & A_Mil1_3 & Mil1 & 2.36 & 41.68 \\
\hline 4 & A_Mil1_4 & Mi11 & 2.36 & 41.68 \\
\hline 4 & A_Mil1_5 & Mil1 & 2.36 & 41.68 \\
\hline 4 & A_Mo01_1 & Mol & 2.41 & 41.74 \\
\hline 4 & A_Mo01_2 & Mo1 & 2.41 & 41.74 \\
\hline 4 & A_Mo01_3 & Mo1 & 2.41 & 41.74 \\
\hline 4 & A_Mo01_4 & Mo1 & 2.41 & 41.74 \\
\hline 4 & A_Mo01_5 & Mo1 & 2.41 & 41.74 \\
\hline 4 & A_Mo02_1 & Mo2 & 2.39 & 41.76 \\
\hline 4 & A_Mo02_2 & Mo2 & 2.39 & 41.76 \\
\hline 4 & A_Mo02_3 & Mo2 & 2.39 & 41.76 \\
\hline 4 & A_Mo02_4 & Mo2 & 2.39 & 41.76 \\
\hline 4 & A_Mo02_5 & Mo2 & 2.39 & 41.76 \\
\hline 4 & A_Mo09-1_ & Mo09 & 2.43 & 41.7 \\
\hline 4 & A_Mo09_2 & Mo09 & 2.43 & 41.7 \\
\hline 4 & A_Mo09_3 & Mo09 & 2.43 & 41.7 \\
\hline 4 & A_Mo09_4_ & Mo09 & 2.43 & 41.7 \\
\hline 4 & A_Mo09_5 & Mo09 & 2.43 & 41.7 \\
\hline 4 & A_Sa01_- & Sal & 2.58 & 41.77 \\
\hline 4 & A_Sa01_2 & Sal & 2.58 & 41.77 \\
\hline 4 & A_Sa01_3 & Sal & 2.58 & 41.77 \\
\hline 4 & A_Sa01_4 & Sal & 2.58 & 41.77 \\
\hline 4 & A_Sa01_5 & Sal & 2.58 & 41.77 \\
\hline
\end{tabular}

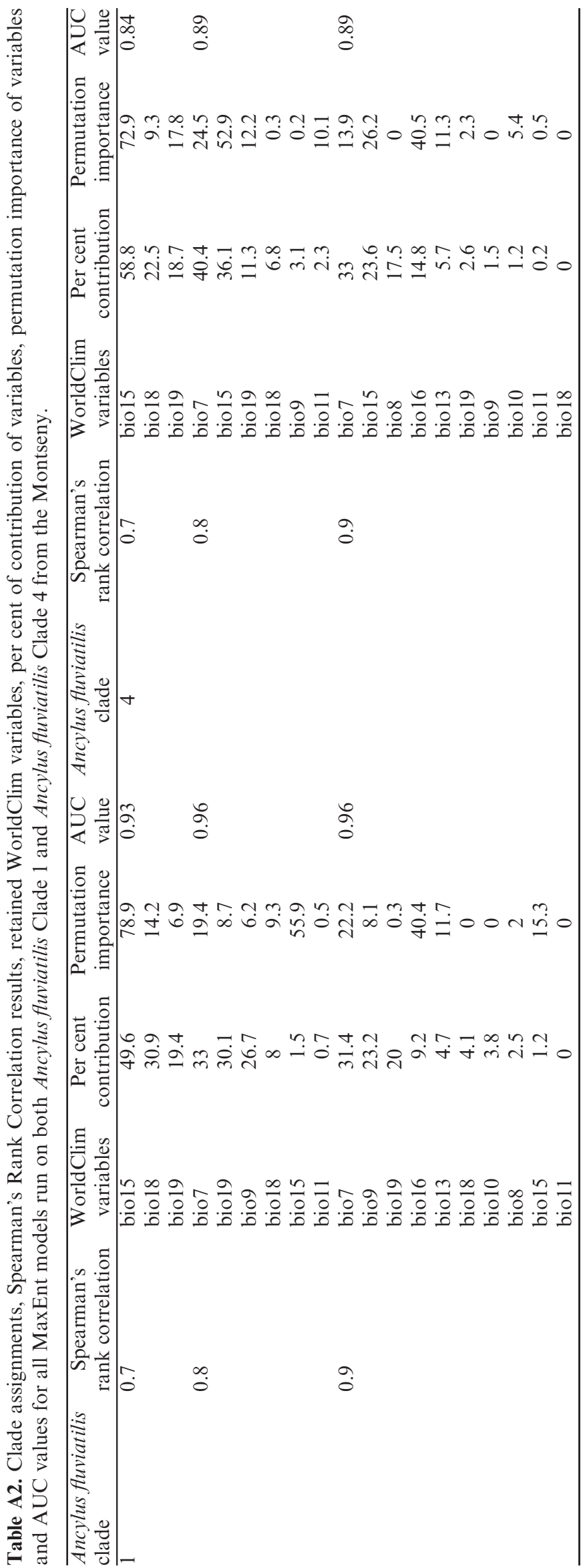


Table A3. Schoener's D bioclimatic niche overlap and range overlap calculated for occurrence likelihood > 50\% for Ancylus fluviatilis Clade 1 and Ancylus fluviatilis Clade 4 in the Montseny, calculated with ENMTools.

Ancylus fluviatilis

Table A4. $\Phi$ ST values between catchments and $\Phi$ ST values between altitude zones for populations of Ancylus fluviatilis Clade 1 and Ancylus fluviatilis Clade 4 in the Montseny. Asterisks indicate $P=<0.05$

\begin{tabular}{|c|c|c|c|c|c|c|c|}
\hline \multicolumn{4}{|c|}{$\Phi_{\text {ST }}$ values between catchments } & \multicolumn{4}{|c|}{$\Phi^{\mathrm{SI}}$ values between altitude zones } \\
\hline \multicolumn{4}{|c|}{ Ancylus fluviatilis Clade 1} & \multicolumn{4}{|c|}{ Ancylus fluviatilis Clade 1} \\
\hline & Tordera & Besòs & Ter & & $<500$ masl & $500-1000$ masl & $>1000$ masl \\
\hline Tordera & 0.00 & & & $<500$ masl & 0.00 & & \\
\hline Besòs & $0.32214 *$ & 0.00 & & $500-1000$ masl & 0.00 & 0.00 & \\
\hline Ter & $0.16665^{*}$ & 0.0664 & 0.00 & $>1000$ masl & $0.34319 *$ & $0.27394 *$ & 0.00 \\
\hline \multicolumn{4}{|c|}{ Ancylus Clade 4} & \multicolumn{4}{|c|}{ Ancylus Clade 4} \\
\hline & Tordera & Besòs & Ter & & $<500$ masl & 500-1000 masl & $>1000$ masl \\
\hline Tordera & 0.00 & & & $<500$ masl & 0.00 & & \\
\hline Besòs & $0.40835^{*}$ & 0.00 & & $500-1-00$ masl & $0.33475^{*}$ & 0.00 & \\
\hline Ter & 0.15213 & $0.87648 *$ & 0.00 & $>1000$ masl & $0.66737 *$ & 0.13043 & 0.00 \\
\hline
\end{tabular}

